This point was taken up in discussion by Prof. J. M. Cameron, of Leeds, who spoke of the importance of popular sovereignty and the dangers of oligarchy. Mr. T. G. Miller, of North Staffordshire, and Mr. H. Maddick, of the Association of University Teachers, supported these arguments, and the former urged the ending of the distinction between 'professorial' and 'non-professorial' teachers.

The problem of the independence of the new institution was raised by Prof. Sykes, and he emphasized the need for local financial and other support. In this he was supported with evidence by Prof. A. K. Stout, of Sydney, and Prof. J. E. Corry, the vice-principal of Queen's University, Ontario, both of whom dealt with some of the problems of political control. A reassurance was offered on this matter by Viscount Mackintosh of Halifax, who described the wide range of support given to Norwich by the University Grants Committee, by the general public, and by industry, commerce and the arts in the counties of Norfolk and Suffolk.

In contrast to the ideas of Mr. Fulton and in support of the thesis of Prof. Sykes, Prof. W. A. C. Stewart, of the University College of North Staffordshire, suggested that slow growth might in fact be the prerequisite of the development of successful interdisciplinary courses, and he pointed out that his institution now has 800 students after ten years growth.

The sense of the conference was--it had no formal resolutions or conclusions - that education in the 'new universities' should be liberal rather than technical in the narrow sense, and should educate the whole man, or woman, for life rather than for a career.

\title{
IMPACT OF MAN ON THE VEGETATION OF THE HUMID TROPICS
}

\begin{abstract}
A $\mathrm{N}$ enterprising and successful symposium, convened by the Unesco South East Asia Science Co-operation Office, was held at Goroka, New Guinea, during September. It was brought to fruition through the generous hospitality of the Administration of Papua and the Territory of New Guinea and the unremitting efforts of J.S. Womersley, chief of the Division of Botany, Department of Forests, Lae. Thirty delegates attended from Australia, India, Indonesia, Malaya, Philippines, Sarawak, Singapore, Thailand, Great Britain, the United States, the Territory of Papua and New Guinea, and the South Pacific Commission. There were also twelve observers from the Territory, among whom Mr. H. P. Seale, district commissioner of the Eastern Highlands, was elected president of the symposium. Delegates arrived at Port Moresby, and on September 14 they were taken by charter-plane across the high mountains to Goroka at an altitude of 5,000 ft. Any doubts about the suitability of the site were soon dispelled by the comfort of the Goroks Hotel and the warm welcome from the district commissioner. In these inspiring surroundings, old in their display of the effects of early man in the valleys and on the mountain-sides, befitting the topic of the symposium, and new in the post-war growth of the administrative centre, a vigorous speech from the assistant administrator, Dr. J. T. Gunther, on behalf of the administrator, Brigadier D. M. Cleland, inaugurated the symposium. It was time, he said, to end not only the wars of man on man, but of man on beasts, and of man on vegetation. He struck a theme which forced itself into the chief recommendation of the meeting. The grandeur of Nature, the poverty of man, and the ideal of human rights surged into the panorama, for the object of the symposium was to bring together agriculturists, botanists, foresters, administrators, anthropologists and geographers in South East Asia and tropical Oceania.

Thirty-six papers had been presented and duplicated for previous study, and an efficient secretariat, brought from Port Moresby, reported the discussions in full. First, the physical and human backgrounds of the humid tropics were considered. Illness prevented
\end{abstract}

Prof. W. A. R. Wikramateleke (Singapore) from giving the opening discourse, and in his place the aspects of climatology were presented by Prof. J. M. Blaut (Yale University), of soils and substrata by Dr. F. R. Fosberg (National Research Council, Washington), and of vegetation by myself. Prof. W. R. Geddes (University of Sydney) followed with a sympathetic approach to the human background, based particularly on his researches in Indo-China and Sarawak; he emphasized the ' $c$ ' in Unesco as the all-important socio-cultural element of human community and, indeed, the mark of man. The second topic, on the selection and cultivation of foods by early man, was introduced by Dr. J. Barrau (South Pacific Commission). He explained how early man was a practical geneticist selecting by taboo which prevented misappropriation and loss of valuable plants, thereby preserving the better yielders in the multitude of wild variety; the procedure was in striking contrast with the tendency to exterminate the valuable beasts. He was directing his studies to the problem of the bread-fruit tree, so widely cultivated in great variety, yet so obviously wild in New Guinea and the Melanesian islands. This important plant, too massive for interpretation in the herbarium, had to be studied in the arboretum, on which task he was bent. The problem of the sweet potato, chased by the peoples of New Guinea from valley to valley in almost maniacal destruction of the forest, raised considerable doubt on its supposed American origin. Fosberg presented his ideas on the origin of the coco-nut as a cultigen, the ancestral form of which botanists had not yet adequately contemplated. Mr. G. P. Keleny (Port Moresby) gave a detailed account, of the basic food-crops of New Guinea. Dr. M. J. Meggitt (University of Sydney) explained his work on the native agricultural methods of the Western Highlands, showing the readiness with which new food-crops may be taken up. Mr. W. L. Conroy (Department of Agriculture, New Guinea), in comparing the effects of indigenous agriculture on soilerosion and soil-deterioration with those of land-slides in forested country, considered that the damage supposed to be caused by deforestation might well be 
exaggerated. He instanced the value of Casuarina in re-afforestation and soil-renewal in the Highlands. Dr. E. Quisumbing (Manila) related how the War had caused many new food-plants to be taken up in the Philippines.

Thirdly came the prolonged discussion on the effects of fire. To most delegates the Highlands presented endless deforestation followed by grassland and incessant burning. They were grateful to $\mathrm{Mr}$. C. F. W. Julius (Port Moresby) for his careful analysis of native land-rights and usage in explanation of this scenery. Achieved in the first place by finger-nails, sticks and stones, and now accelerated by trenching tools, knives and matchets, with a wanton love of burning for fun, yet there was little evidence in New Guinea of deterioration into desert conditions. Nevertheless, the question was raised whether the replace ment of forest by grassland caused a lower rainfall, such as certainly followed the wake of the gold. dredging in the Bulolo district. The discussion revealed the abundance of observation, the thicket of conjecture, and the lack of scientific inquiry.

Fourthly, in an able discourse on grasslands, Dr. W. Bryan (Brisbane) opened the session on the effects of grazing by the domestic animals of early man. New Guinea was a great contrast to Africa. Deforestation led to grasslands, but the absence of any indigenous grazing animals was reflected even in the reluctance among natives to adopt cattle-farming. Though all became grass under native agriculture, there was so little flesh. Anthropologists joined with agriculturists in presenting this problem of induced pastoralism, extending into tropical Oceania, as a concern for Unesco. A remarkable paper on the status of the pig in New Guinea was read by Julius on behalf of Mr. T. Aitcheson (Port Moresby).

Fifthly, the effects of shifting eultivation on the vegetation of the humid tropies were considered. Mr. J. A. R. Anderson (Sarawak) described the carefully planned experiment on regeneration of cleared areas which was in progress in Sarawak. Contributions were made by Dr. I. Y. Carey (Malaya) on the methods of the Temiar people, by T. Smitinand (Thailand), E. Quisumbing (Philippines), Y. Satyanaryan (India) and D. J. Kingston (Port Moresby). What had been an economical cycle for soil-regeneration seemed now in all countries to be becoming uneconomical as increasing population shortened the fallow-period through the demand for more land in use. It was much regretted that no observer from the Food and Agriculture Organization had been able to attend this meeting.

Sixthly, there was a discussion on the nature of secondary plant-communities arising from the activity of early man. Fosberg introduced the subject with a general review of such communities. Dr. R. G. Robbins (Canberra) outlined the results of his researches on the Now Guinea grasslands; the full publication of this work will be most instructive. Mr. J. J. Havel (Rabaul) gave two valuable papers on his experimental approach to forest regeneration in eastern New Guinea. Mr. E. C. G. Gray described the remarkably efficient sylviculture of mangroveforest developed on their own by the natives in the Gulf of Papua.

Lastly, the social and economic aspects of early man's action on the forests were considered. Mrs. K. V. Bailey described the dire effects of overpopulation in the denuded limestone country of Java. Keleny described the land-use patterns in Java. Dr.
I. Polunin (Singapore) discussed the aspects of human health and disease under conditions of shifting cultivation which tend to prevent intensification of parasitic attack.

This symposium touched on many vast problems, requiring the attention of both pure and applied science. The delegates were, indeed, grateful to $\mathbf{M r}$. L. Mattsson, director of the Unesco South East Asia Science Co-operation Office, for his help in enabling them to escape from their isolation in this huge region, to join in such fertile discussion, and to formulate in a set of resolutions to Unesco what they considered to be the most urgent matters for investigation. Herein they were assisted in no small measure by the hospitality of the Administration which had arranged two magnificent excursions by air and land-rover to enable them to sec the natural vegetation, the grand mountain scenery, the happy native peoples and, indeed, the fine work of the Administration itself in the Highlands of the Territory. We flew in the early morning around Mt. Wilhelm $(15,400 \mathrm{ft}$.) and its alpine slopes, glacial valleys, and many peaks in a cloudless sky. We picnicked in Nothofagus forests. We were the guests of the beautiful township of Kundiava in the Upper Chimbu. We visited the property of the Halstrom Fauna Trust at Nondugl, where birds-of-paradise are bred-and what an ornithological field-station it would make. Mr. Womersley took the botanists to Kainantu, whence they visited the agricultural station at Aiyura on the way to the scenic junction of the Ramu and Markham valleys, and they were taken along the great Markham valley in a spectacular flight to their destination at Lae. Dr. Meggitt took the anthropologists and geographers to the northern district of Madang. Some of us stayed on in the busy verdant town of Lae on the shore of the Huon Gulf and enjoyed the beautiful Botanic Garden, which is under the direction of Mr. Womersley. It was a delight to find this seat of learning. Started on August 1, 1949, from a waste of wild sugar-cane, it now covers some 120 acres of lawns, flower-beds, plant-houses, woodland, and wooded streams. The new office and herbarium, which are planned, will be the Mecca of Melanesian botany, and the next ten years should see the perfection of the first. Here, several of us, from different lands, walked and talked, consolidating our views on the symposium; as Fosberg sagely remarked, a requisite of a delegate to such a pioneering conference should be his ability to stay a while and contribute to the knowledge of the country.

The eight resolutions concerning South East Asia and Tropical Oceania directed to Unesco dealt with the needs for: (1) the study of secondary plant. cornmunities produced by human disturbance of the tropical forest; (2) the promotion of ethnobotany; (3) the effects of alien civilization on primitive peoples ; (4) the study of the vegetation of limestone formations, so susceptible to destruction by fire and other causes ; (5) the urgent need for programmes of consideration of natural resources; (6) the study of root physiology in the furtherance of soil science ; (7) research into the socio-economic adaptation of recently contacted native people; (8) the convening of another symposium within the region of the South East Asia Science Co-operation Office in view of the stimulus given already to scientific and cultural understanding by the previous ones.

E. J. H. CORNER 